\title{
Iron Oxide Doped Alumina-Zirconia Nanoparticle Synthesis by Liquid Flame Spray from Metal Organic Precursors
}

\author{
Juha-Pekka Nikkanen, ${ }^{1}$ Helmi Keskinen, ${ }^{2}$ Mikko Aromaa, ${ }^{2}$ Mikael Järn, ${ }^{3}$ Tomi Kanerva, ${ }^{1}$ \\ Erkki Levänen, ${ }^{1}$ Jyrki M. Mäkelä, $^{2}$ and Tapio Mäntylä ${ }^{1}$ \\ ${ }^{1}$ Department of Materials Science, Tampere University of Technology, P.O. Box 589, 33101 Tampere, Finland \\ ${ }^{2}$ Aerosol Physics Laboratory, Department of Physics, Tampere University of Technology, P.O. Box. 692, 33101 Tampere, Finland \\ ${ }^{3}$ Laboratory for Physical Chemistry, Åbo Akademi University, 20500 Åbo, Finland
}

Correspondence should be addressed to Juha-Pekka Nikkanen, juha-pekka.nikkanen@tut.fi

Received 11 March 2008; Accepted 23 April 2008

Recommended by Chuan-Jian Zhong

\begin{abstract}
The liquid flame spray (LFS) method was used to make iron oxide doped alumina-zirconia nanoparticles. Nanoparticles were generated using a turbulent, high-temperature $\left(T_{\max } \sim 3000 \mathrm{~K}\right) \mathrm{H}_{2}-\mathrm{O}_{2}$ flame. The precursors were aluminium-isopropoxide, zirconium- $n$-propoxide, and ferrocene in xylene solution. The solution was atomized into micron-sized droplets by high velocity $\mathrm{H}_{2}$ flow and introduced into the flame where nanoparticles were formed. The particle morphology, size, phase, and chemical composition were determined by TEM, XRD, XPS, and $\mathrm{N}_{2}$-adsorption measurements. The collected particulate material consists of micron-sized aggregates with nanosized primary particles. In both doped and undoped samples, tetragonal phase of zirconia was detected in room temperature while alumina was found to be noncrystalline. In the doped powder, $\mathrm{Fe}_{\text {was }}$ oxidized to $\mathrm{Fe}_{2} \mathrm{O}_{3}$. The primary particle size of collected sample was approximately from $6 \mathrm{~nm}$ to $40 \mathrm{~nm}$. Doping was observed to increase the specific surface area of the powder from $39 \mathrm{~m}^{2} / \mathrm{g}$ to $47 \mathrm{~m}^{2} / \mathrm{g}$.
\end{abstract}

Copyright (C) 2008 Juha-Pekka Nikkanen et al. This is an open access article distributed under the Creative Commons Attribution License, which permits unrestricted use, distribution, and reproduction in any medium, provided the original work is properly cited.

\section{INTRODUCTION}

Liquid flame spray (LFS) technique can be used to synthesize the broad spectrum of inorganic oxide nanoparticles like $\mathrm{Al}_{2} \mathrm{O}_{3}, \mathrm{ZrO}_{2}, \mathrm{Mn}_{2} \mathrm{O}_{3},[1,2], \mathrm{TiO}_{2}$ [3], $\mathrm{Fe}_{2} \mathrm{O}_{3}, \mathrm{Fe}_{3} \mathrm{O}_{4}$ [4], and nanoscale metallic particles like $\mathrm{Ag}$ and $\mathrm{Pd}$ [4]. Liquid feeding-based flame methods also offer a controlled way to synthesize mixed oxides like $\mathrm{MgAl}_{2} \mathrm{O}_{4}, \mathrm{CeO}_{2} / \mathrm{ZrO}_{2}, \mathrm{Y}_{2} \mathrm{O}_{3}$ $\mathrm{ZrO}_{2}$ [1], and $\mathrm{SiO}_{2} / \mathrm{TiO}_{2}$ [5]. In Liquid flame spray (LFS), a high-velocity high-temperature flame is used to produce nanoparticles. Liquid precursor is axially injected into the flame where it evaporates, decomposes, reacts, and finally nucleates to the nanosized particles. Particles can be deposited directly on the substrate as a layer [6], or collected from gas stream by filters [7] or by electrostatic precipitators [3].

The unique properties of nanoscale materials offer several interesting applications in different fields of industry. The remarkable optical, electronic, magnetic, and mechanical properties of nanoparticles and materials made of na- noparticles open up a possibility to modify the functionality of electrochemical, photochemical and structural materials, and coatings $[8,9]$. A fractional size and controlled shape of metal and functionalized metal nanoparticles, as well as properties of doped mixed oxides like $\mathrm{Al}_{2} \mathrm{O}_{3}-\mathrm{ZrO}_{2}$, could provide a unique possibility for highly efficient catalysis $[9,10]$. The catalysis provides numerous applications like alkylation and isomerization in the chemical industry $[10,11]$, catalytic reduction of $\mathrm{NO}$ and $\mathrm{NH}_{3}$ [12], or preparation of carbon nanotube- $\mathrm{Al}_{2} \mathrm{O}_{3}$ composites with $\mathrm{Fe}$ catalysts [13]. Several applications of the catalytic agents together with increasing demand of high-quality structural materials call for new and controllable methods to produce nanoscale building blocks. LFS technique opens up a possibility to produce multicomponent oxide nanomaterials together with additional catalyst for further designing and processing of functional or structural nanomaterials.

The aim of this work was to demonstrate the synthesis of iron oxide doped $\mathrm{Al}_{2} \mathrm{O}_{3}-\mathrm{ZrO}_{2}$ mixed oxide by an LFS. 


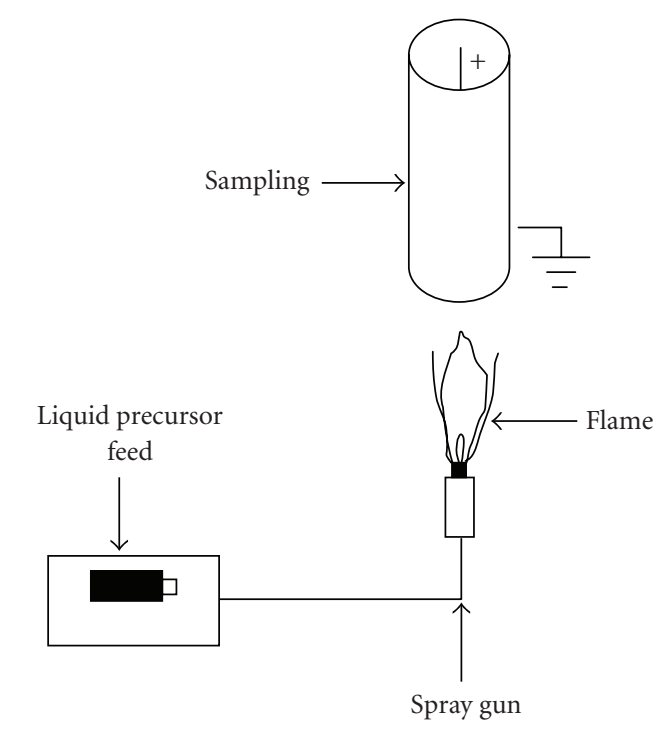

FIgURE 1: Schematic description of the LFS-process [3].

The collected particles were analyzed in order to determine resulting particle size, morphology, phases, and chemical composition. The characteristics of iron oxide doped sample were compared to the undoped sample.

\section{EXPERIMENTAL}

Aluminium isopropoxide $\left(\mathrm{C}_{9} \mathrm{H}_{21} \mathrm{AlO}_{3}\right)$, zirconium (IV) $n$ propoxide $\left(\mathrm{Zr}\left[\mathrm{O}\left(\mathrm{CH}_{2}\right)_{2} \mathrm{CH}_{3}\right]_{4}\right)$, and ferrocene $\left(\left(\mathrm{C}_{5} \mathrm{H}_{5}\right)_{2} \mathrm{Fe}\right)$ were dissolved in p-xylene. Molar ratio of $\left(\mathrm{C}_{9} \mathrm{H}_{21} \mathrm{AlO}_{3}\right)$ : $\left(\mathrm{Zr}\left[\mathrm{O}\left(\mathrm{CH}_{2}\right)_{2} \mathrm{CH}_{3}\right]_{4}\right):\left(\left(\mathrm{C}_{5} \mathrm{H}_{5}\right)_{2} \mathrm{Fe}\right)$ in precursor solution was $52: 22: 1$. Also in undoped solution, the molar ratio of $\left(\mathrm{C}_{9} \mathrm{H}_{21} \mathrm{AlO}_{3}\right):\left(\mathrm{Zr}\left[\mathrm{O}\left(\mathrm{CH}_{2}\right)_{2} \mathrm{CH}_{3}\right]_{4}\right)$ was $52: 22$. The precursor solution was fed into turbulent, high-temperature $\mathrm{H}_{2}$ $\mathrm{O}_{2}$ flame. The feed rate was $5.2 \mathrm{~mL} / \mathrm{min}$. The gas flows were $20 \mathrm{~L} / \mathrm{min}$ for $\mathrm{H}_{2}$ and $10 \mathrm{~L} / \mathrm{min}$ for $\mathrm{O}_{2}$. Liquid precursor was atomized in the high-velocity $\mathrm{H}_{2}$ flow into micron-sized droplets and introduced into oxygen stream and the upwards directed flame where particles were formed. Particles were collected by a cylindrical electrostatic precipitator with a diameter of $100 \mathrm{~mm}$ and length of $1000 \mathrm{~mm}$, using $6.0 \mathrm{kV}$ voltage on the central rod, and $0.3 \mathrm{~mA}$ current from rod to grounded cylinder. Total amount of collected material was in the order of one gram. LFS-process is schematically illustrated in Figure 1.

The crystal structure of the sample was determined by X-ray diffractometer (Kristalloflex D-500, Siemens) using monochromatized $\mathrm{CuK}_{\alpha}$ radiation. The particle morphology was determined by a transmission electron microscope (TEM) (JEOL, JEM 2010). Then the specific surface area of sample was measured by nitrogen adsorption using the Brunauer-Emmett-Teller (BET) method (Coulter Omnisorp $100 \mathrm{cx}$ ). The X-ray photoemission (XPS) spectra were recorded using a Physical Electronics Quantum 2000 ESCA instrument. The XPS measurements were performed at a base pressure of $1 \times 10^{-9}$ torr using the $\mathrm{AlK}_{\alpha} \mathrm{X}$-ray source. Operating power was $12.5 \mathrm{~kW}$ and the spot diameter $50 \mu \mathrm{m}$.

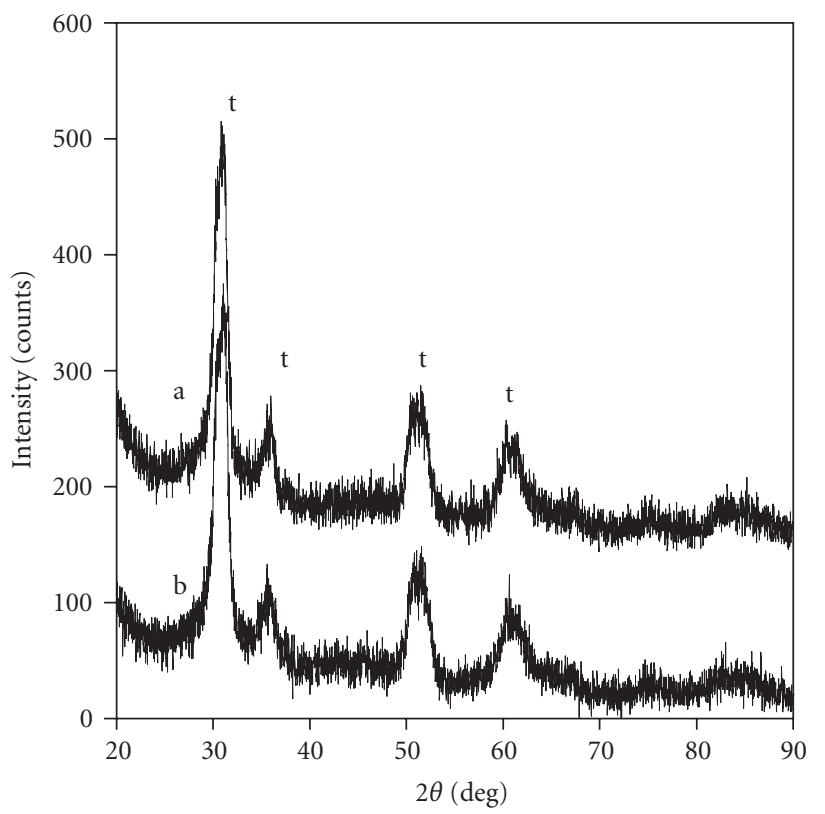

FIGURE 2: XRD-diffraction pattern of $\mathrm{Al}_{2} \mathrm{O}_{3}-\mathrm{ZrO}_{2}$ (a) and iron oxide doped $\mathrm{Al}_{2} \mathrm{O}_{3}-\mathrm{ZrO}_{2}$ mixed oxide (b); $t$ : tetragonal- $\mathrm{ZrO}_{2}$.

The low and high resolutions of pass energy in spectral acquisition were 117.4 and $23.5 \mathrm{eV}$, respectively. Surface concentrations were determined with Multipak 6.1 software using peak areas to give surface concentrations in atomic percent.

\section{RESULTS AND DISCUSSION}

The XRD diffraction patterns (Figure 2) of LFS particulate materials contained only the peaks of tetragonal $\mathrm{ZrO}_{2}$. Since no other than $t-\mathrm{ZrO}_{2}$ was detected, $\mathrm{Al}$ and $\mathrm{Fe}$ are probably in amorphous phase.

The XPS spectra of the collected samples are shown in Figure 3. In XPS measurements, iron was detected and the Fe $2 \mathrm{p}_{3 / 2}$ peak position was around $711 \mathrm{eV}$, indicating that most of the iron is $\mathrm{Fe}_{2} \mathrm{O}_{3}$. The $\mathrm{Al} 2 \mathrm{p}$ peak position was around $73.8 \mathrm{eV}$ and position of $\mathrm{Zr} 3 \mathrm{~d}_{3 / 2}$ peak around $186 \mathrm{eV}$ which proves that both $\mathrm{Al}$ and $\mathrm{Zr}$ are oxidized to $\mathrm{Al}_{2} \mathrm{O}_{3}$ and $\mathrm{ZrO}_{2}$. The signal at around $285 \mathrm{eV}$ corresponds to adventitious carbon.

The surface concentrations of oxygen, aluminum, zirconium, and iron, in atomic percent, are given in Table 1. From the high-resolution XPS spectra, the calculated concentrations are compared to the theoretical acquisition of named atoms. From XPS spectra, calculated concentrations of oxygen and iron are higher whereas the concentrations of aluminum and zirconium are lower than the theoretical acquisition. It is supposed that there is adsorbed oxygen and meanwhile more $\mathrm{Fe}_{2} \mathrm{O}_{3}$ particles on the surface of the sample than inside of it.

The specific surface area of the doped sample was $46.7 \mathrm{~m}^{2} / \mathrm{g}$ whereas it was $38.8 \mathrm{~m}^{2} / \mathrm{g}$ for undoped sample. Higher surface area of doped sample refers to small size of $\mathrm{Fe}_{2} \mathrm{O}_{3}$ particles. Another explanation for the increase of 
TABLE 1: Calculated surface concentrations in atomic percentage from XPS (1) and theoretical acquisition (2) of oxygen, aluminum, zirconium, and iron of $\mathrm{Fe}_{2} \mathrm{O}_{3}+\mathrm{Al}_{2} \mathrm{O}_{3}-\mathrm{ZrO}_{2}$ and $\mathrm{Al}_{2} \mathrm{O}_{3}-\mathrm{ZrO}_{2}$.

\begin{tabular}{|c|c|c|c|c|c|}
\hline & Sample & Oxygen at $-\%$ & Aluminum at $-\%$ & Zirconium at $-\%$ & Iron at $-\%$ \\
\hline (1) & $\mathrm{Fe}_{2} \mathrm{O}_{3}+\mathrm{Al}_{2} \mathrm{O}_{3}-\mathrm{ZrO}_{2}$ & 71.01 & 22.35 & 5.87 & 0.77 \\
\hline (2) & $\mathrm{Fe}_{2} \mathrm{O}_{3}+\mathrm{Al}_{2} \mathrm{O}_{3}-\mathrm{ZrO}_{2}$ & 61.91 & 26.49 & 11.09 & 0.51 \\
\hline (1) & $\mathrm{Al}_{2} \mathrm{O}_{3}-\mathrm{ZrO}_{2}$ & 71.37 & 22.53 & 6.10 & - \\
\hline (2) & $\mathrm{Al}_{2} \mathrm{O}_{3}-\mathrm{ZrO}_{2}$ & 62.23 & 26.63 & 11.15 & - \\
\hline
\end{tabular}

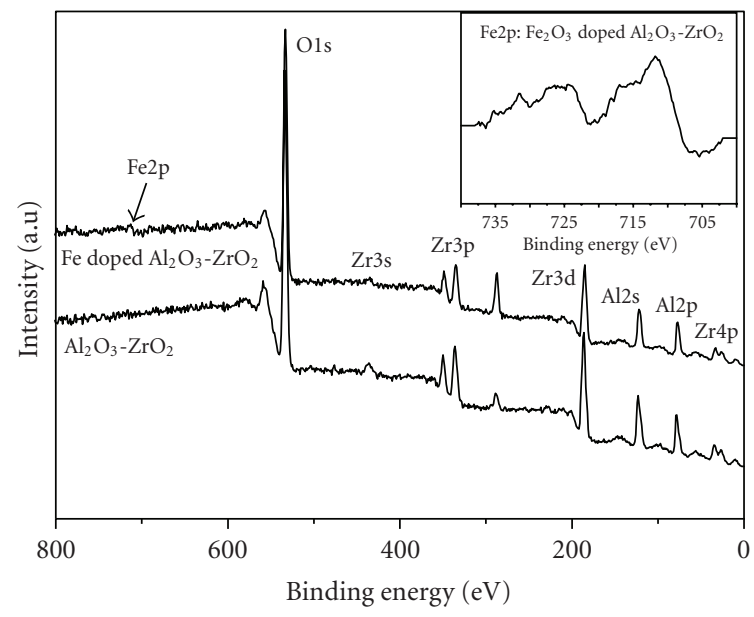

Figure 3: XPS survey spectra of $\mathrm{Al}_{2} \mathrm{O}_{3}-\mathrm{ZrO}_{2}$ and $\mathrm{Fe}_{2} \mathrm{O}_{3}$ doped $\mathrm{Al}_{2} \mathrm{O}_{3}-\mathrm{ZrO}_{2}$ mixed oxide. The insert in the figure represents the $\mathrm{Fe}$ 2p high-resolution spectra of $\mathrm{Fe}_{2} \mathrm{O}_{3}$ doped $\mathrm{Al}_{2} \mathrm{O}_{3}-\mathrm{ZrO}_{2}$.

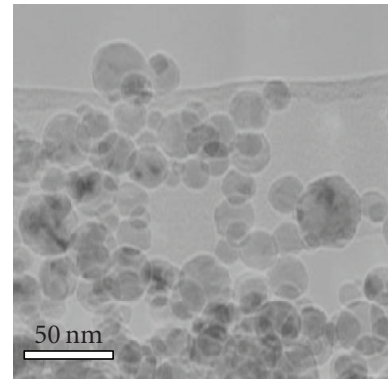

(a)

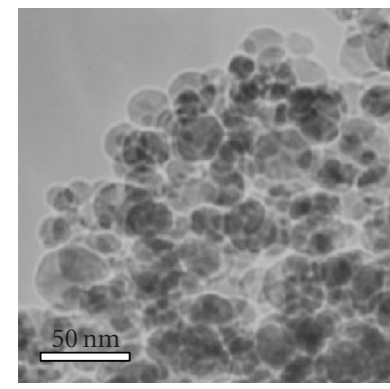

(b)
FIgURE 4: TEM micrograph of $\mathrm{Fe}_{2} \mathrm{O}_{3}$ doped $\mathrm{Al}_{2} \mathrm{O}_{3}-\mathrm{ZrO}_{2}$ (a) and $\mathrm{Al}_{2} \mathrm{O}_{3}-\mathrm{ZrO}_{2}$ mixed oxide (b).

specific surface area may be the decreased particle size. Anyway, the difference is so small that it cannot be observed in the peak width in the XRD patterns (Figure 2), but the phenomenon has been observed in earlier studies $[3,14]$. The TEM images of the collected samples are shown in Figure 4. The primary particle size as estimated from TEM graphs is approximately from 6 to $40 \mathrm{~nm}$ in both, doped (Figure 4(a)) and undoped (Figure 4(b)) samples. The slightly higher specific surface area of doped sample is probably caused by less dense packing or increased surface irregularities caused by small $\mathrm{Fe}_{2} \mathrm{O}_{3}$ particles. The shape of the particles is mainly spherical in doped and undoped samples.

The crystallite size of $t-\mathrm{ZrO}_{2}$ was estimated from XRD pattern by using Scherrer's formula $t=(0.9 \lambda / B \cos \theta)$ [15], where $t$ is in $\mathrm{nm}, \lambda$ the wavelength of X-ray in $\AA(1.5418 \AA)$, $B$ is the full width half maxima in radians, and $\theta$ is the Bragg angle. This calculation gave the size of $7.4 \mathrm{~nm}$ for both samples. Zirconia has a monoclinic phase structure at low temperature and at normal pressure. The martensitic transformation upon heating to tetragonal phase occurs approximately at about $1150^{\circ} \mathrm{C}$, whereas reverse transformation upon cooling occurs at about $900^{\circ} \mathrm{C}$ because of the hysteresis effect $[2,16]$. The presence of tetragonal $\mathrm{ZrO}_{2}$ at low temperature can be explained by the small size of the crystals. Phase transformation from tetragonal to monoclinic occurs at a critical crystal size of $8-18 \mathrm{~nm}$. Tetragonal phase is thermodynamically stable if the size of the crystals is below that $[2,17]$.

\section{CONCLUSIONS}

Iron oxide doped nanoscale $\mathrm{Al}_{2} \mathrm{O}_{3}-\mathrm{ZrO}_{2}$ mixed oxide was prepared by liquid flame spray. The crystal structure, particle and crystal size, specific surface area, and surface concentrations of the elements were analyzed. Analysis using XRD showed that the structure of alumina is not crystalline, whereas zirconia exists in tetragonal phase. According to XPS study, $\mathrm{Fe}$ exists mostly in oxide $\left(\mathrm{Fe}_{2} \mathrm{O}_{3}\right)$. On the grounds of the TEM dissection, the particle size of the sample is in nanometer scale. The calculated crystallite size of zirconia was found to be $7.4 \mathrm{~nm}$. In small particles, the tetragonal structure is energetically favorable. This gives the explanation to the existence of the tetragonal form of zirconia at the room temperature.

\section{ACKNOWLEDGMENT}

This work is partially supported by EU research project IP NANOKER (FP6-515784-2).

\section{REFERENCES}

[1] J. Karthikeyan, C. C. Berndt, J. Tikkanen, J. Y. Wang, A. H. King, and H. Herman, "Nanomaterial powders and deposits prepared by flame spray processing of liquid precursors," Nanostructured Materials, vol. 8, no. 1, pp. 61-74, 1997.

[2] R. Mueller, R. Jossen, S. E. Pratsinis, M. Watson, and M. K. Akhtar, "Zirconia nanoparticles made in spray flames at high 
production rates," Journal of the American Ceramic Society, vol. 87, no. 2, pp. 197-202, 2004.

[3] H. Keskinen, J. M. Mäkelä, M. Aromaa, et al., "Titania and titania-silver nanoparticle deposits made by liquid flame spray and their functionality as photocatalyst for organic- and biofilm removal," Catalysis Letters, vol. 111, no. 3-4, pp. 127132, 2006.

[4] J. M. Mäkelä, H. Keskinen, T. Forsblom, and J. Keskinen, "Generation of metal and metal oxide nanoparticles by liquid flame spray process," Journal of Materials Science, vol. 39, no. 8, pp. 2783-2788, 2004.

[5] S. H. Ehrman, S. K. Friedlander, and M. R. Zachariah, "Characteristics of $\mathrm{SiO}_{2} / \mathrm{TiO}_{2}$ nanocomposite particles formed in a premixed flat flame," Journal of Aerosol Science, vol. 29, no. 5-6, pp. 687-706, 1998.

[6] J. M. Mäkelä, S. Hellstén, J. Silvonen, M. Vippola, E. Levänen, and T. Mäntylä, "Collection of liquid flame spray generated $\mathrm{TiO}_{2}$ nanoparticles on stainless steel surface," Materials Letters, vol. 60 , no. 4, pp. 530-534, 2006.

[7] R. Strobel, W. J. Stark, L. Mädler, S. E. Pratsinis, and A. Baiker, "Flame-made platinum/alumina: structural properties and catalytic behaviour in enantioselective hydrogenation," Journal of Catalysis, vol. 213, no. 2, pp. 296-304, 2003.

[8] M. Gell, "Application opportunities for nanostructured materials and coatings," Materials Science and Engineering A, vol. 204, no. 1-2, pp. 246-251, 1995.

[9] L. M. Liz-Marzan and P. V. Kamat, Nanoscale Materials, Kluwer Academic Publishers, New York, NY, USA, 2003.

[10] B. M. Reddy, P. M. Sreekanth, Y. Yamada, and T. Kobayashi, "Surface characterization and catalytic activity of sulfate-, molybdate- and tungstate-promoted $\mathrm{Al}_{2} \mathrm{O}_{3}-\mathrm{ZrO}_{2}$ solid acid catalysts," Journal of Molecular Catalysis A, vol. 227, no. 1-2, pp. 81-89, 2005.

[11] J. R. Sohn and D. H. Seo, "Preparation of new solid superacid catalyst, zirconium sulfate supported on $\gamma$-alumina and activity for acid catalysis," Catalysis Today, vol. 87, no. 1-4, pp. 219-226, 2003.

[12] W. J. Stark, K. Wegner, S. E. Pratsinis, and A. Baiker, "Flame aerosol synthesis of vanadia-titania nanoparticles: structural and catalytic properties in the selective catalytic reduction of NO by $\mathrm{NH}_{3}$," Journal of Catalysis, vol. 197, no. 1, pp. 182-191, 2001.

[13] A. Peigney, Ch. Laurent, O. Dumortier, and A. Rousset, "Carbon nanotubes-Fe-alumina nanocomposites. Part I: influence of the Fe content on the synthesis of powders," Journal of the European Ceramic Society, vol. 18, no. 14, pp. 1995-2004, 1998.

[14] H. Keskinen, J. M. Mäkelä, M. Aromaa, et al., "Effect of silver addition on the formation and deposition of titania nanoparticles produced by liquid flame spray," Journal of Nanoparticle Research, vol. 9, no. 4, pp. 569-588, 2007.

[15] B. D. Cullity, Elements of X-Ray Diffraction, Addison-Wesley, Reading, Mass, USA, 1967.

[16] E. Ryshkeniwith and D. W. Richerson, Oxide Ceramics, Academic Press, New York, NY, USA, 1995.

[17] A. Navrotsky, "Energetics of nanoparticle oxides: interplay between surface energy and polymorphism," Geochemical Transactions, vol. 4, pp. 34-37, 2003. 

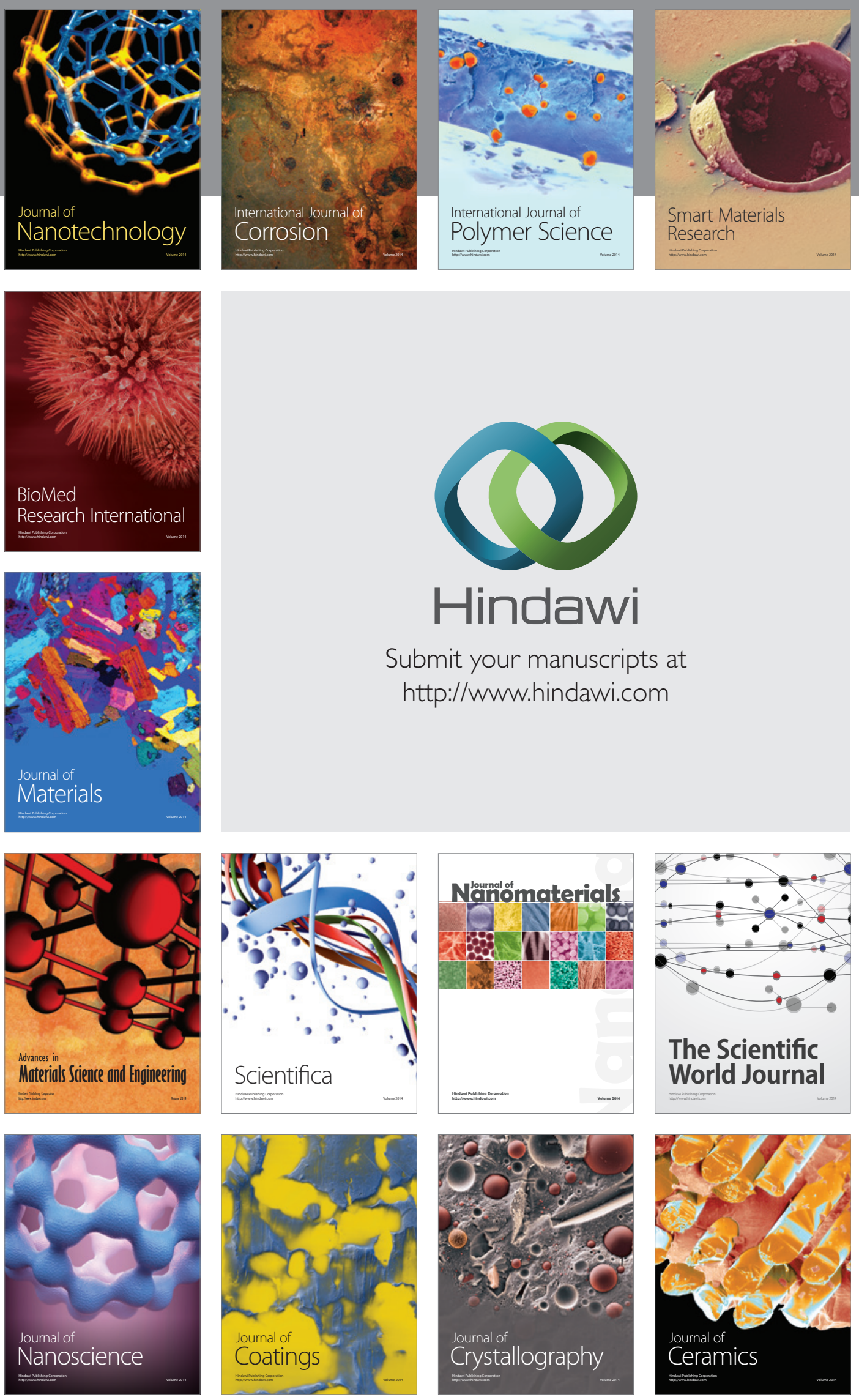

The Scientific World Journal

Submit your manuscripts at

http://www.hindawi.com

\section{World Journal}

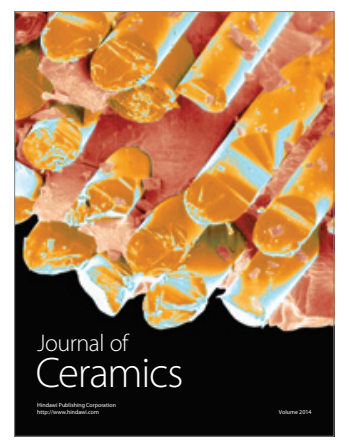

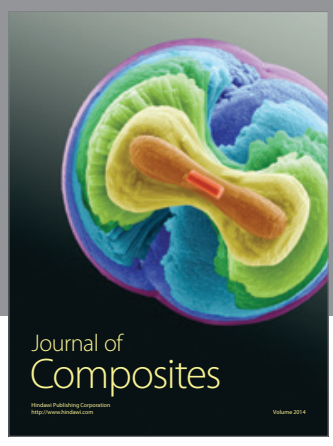
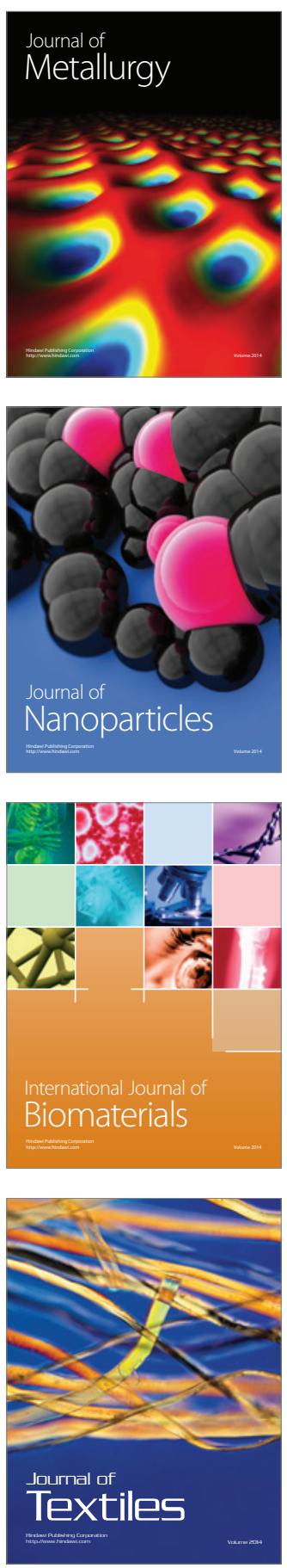